\title{
Author Correction: Molecular basis for heat desensitization of TRPV1 ion channels
}

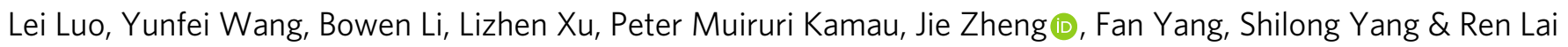

Correction to: Nature Communications https://doi.org/10.1038/s41467-019-09965-6, published online 13 May 2019

The original version of the Source Data file associated with this Article contained errors in the data underlying Figure 1i and Figure 5a. The HTML has been updated to include a corrected version of Source Data file.

Published online: 07 April 2020

\begin{abstract}
(c) (i) Open Access This article is licensed under a Creative Commons Attribution 4.0 International License, which permits use, sharing, adaptation, distribution and reproduction in any medium or format, as long as you give appropriate credit to the original author(s) and the source, provide a link to the Creative Commons license, and indicate if changes were made. The images or other third party material in this article are included in the article's Creative Commons license, unless indicated otherwise in a credit line to the material. If material is not included in the article's Creative Commons license and your intended use is not permitted by statutory regulation or exceeds the permitted use, you will need to obtain permission directly from the copyright holder. To view a copy of this license, visit http://creativecommons.org/licenses/by/4.0/.
\end{abstract}

(C) The Author(s) 2020 